\title{
Public Service Announcement Implementation of Learning at the Sriwijaya State Polytechnic in Minimizing the Risks and Impacts Caused by the Covid-19 Pandemic
}

\author{
Alan Novi Tompunu ${ }^{1, *}$ Nelly Masnila ${ }^{2}$ Zakaria $^{3}$ Azwardi $^{1}$ Ainun Nabila ${ }^{1}$ \\ ${ }^{1}$ Computer Engineering Department, State Polytechnic of Sriwijaya, Indonesia \\ ${ }^{2}$ Accounting Department, State Polytechnic of Sriwijaya, Indonesia \\ ${ }^{3}$ English Department, State Polytechnic of Sriwijaya, Indonesia \\ *Corresponding author.Email: alvito.polsri@gmail.com
}

\begin{abstract}
The spread of Covid19 in Indonesia has not shown any signs of decreasing, therefore the Ministry of Education and culture took preventive steps in the educational environment by issuing a decree which agreed that the learning process, especially in higher education, was carried out online for theoretical courses. However, if it involves graduation and practicum that cannot be carried out online, these activities can be held while prioritizing the health and safety of students, lecturers, and employees. This motion graphic animation video is made using animation maker software, which goes through pre-production, production, and post-production stages. The development method used in this research is the Multimedia Development Method which consists of the engineering testing phase, which is testing whether the motion graphic animation video is running as expected and testing the respondents to find out whether this motion graphic animation video can convey information to students, lecturers. and employees at the Sriwijaya State Polytechnic. The results of the research on respondents stated strongly that there were 29 people (72.5\%) who agreed that there were 11 people (27.5\%), and there were no respondents who expressed doubt, disagreed, and strongly disagreed. So it can be concluded that this motion graphic animation video can make respondents understand the procedures for implementing learning at the Sriwijaya State Polytechnic during the adaptation period of the new Covid19 habit, by displaying attractive graphics and audio so that it is effective as a medium of information. This motion graphic animation video has a duration of 2 minutes 4 seconds.
\end{abstract}

Keywords: Public Service Announcement, Motion Graphic Animation Video, Learning Implementation Guide

\section{INTRODUCTION}

The spread of Covid-19 in Indonesia has not shown any signs decline, therefore the Ministry of Education and Culture took it preventive measures in the educational environment by issuing a decree who agreed that the learning process, especially in higher education, was carried out online for theoretical courses. However, when it comes to graduation and a practicum that cannot be carried out online then these activities can held while prioritizing student health and safety, lecturers and staff [1]. Public service advertisements are non-commercial advertisements with a purpose invite, educate, direct, or encourage the community as citizens countries and citizens of the world. This shows that advertising can be used

as a medium to promote and disseminate information which can be a reminder to the community (the audience). Based on this, the information conveyed in service advertisements this society must be more interesting to watch, as well as necessary good visualization so that the message conveyed is easy to understand. This matter can be realized by maximizing the graphic side (display) and audio quality, to have continuity between visuals and explanations. Generally, service advertisements people use live shoot techniques, which are techniques that display visuals in the form of 
real videos directly which are the result of the shooting process which has been done. However, there were too many live shoot techniques like this used so that it does not give a unique impression to the community because it is visual what is displayed is common and well known. Therefore, the authors chose to develop this public service ad video into an ad video combined with 2D animation media, so that it gives a new impression with attractive visual graphics to be known by all circles, both students, lecturers, and staff at Sriwijaya State Polytechnic. Information to be delivered is a guide for the implementation of learning at the State Polytechnic Sriwijaya during the adaptation period for the new covid habit19. By using media like this, it is hoped that the socialization process will become more effective because information can be spread quickly and evenly, and more interesting and easy to understand.

\section{LITERATURE REVIEW}

Covid-19 or coronavirus disease 2019 is a new disease type caused by a virus from the coronavirus class, namely SARS-CoV-2 which is frequently called the Coronavirus. Covid-19 can cause respiratory system disorders, ranging from mild symptoms such as flu, to lung infections, such as pneumonia.

The New Habit Adaptation Period is a time when the case level confirmed that the coronavirus is still high, but the community is expected to implement its health protocol with discipline in activities to slow down numbers the spread of the virus.

The term multimedia consists of two words, namely multi and media. Definition multi means a lot or more than one, meanwhile the word media tool/means/tools to communicate. Communication is a two-way relationship or interaction. With communication, the information will be easily understood by the senses. Multimedia is a combination of text, art, sound, animation, and video delivered by computer or electronic and digital manipulation equipment. Multimedia is the use of computers to create and combine text, graphics, audio, moving images (video and animation) by combining links and tools that allow users to navigate, interact, create, and communicate.[2]

in multimedia there are several elements, elements include text, images, audio, video, and animation. [5]

\section{Text}

The easiest form of multimedia data to be stored and controlled is text (text). Text requirements depend on the use of multimedia applications.

2. Image

Image (graphic) is the result of an image retrieval obtained through image capture tools, such as cameras and scanners, whose results are frequently called a picture. Images can be in the form of an icon, photo, or symbol.

3. Audio
Audio (sound) is a multimedia component that can take the form of narration, music, sound effects, or a combination of the three.

4. Videos

Video is a presentation of images and sound captured by a camera, then arranged into a sequence of frames to be read in units of seconds.

5. Animation

The animation is the use of computers to create motion on a layer. Animation creation consists of three stages, namely, modeling, layout and animation, and rendering.

Furthermore, the system development methodology refers to the Method Luther's Multimedia Development, [4]. As for a series of activities carried out in the development of this system based onnThe methodologies include:

1. The concept stage (conceptualization), which is determining objectives, including identification audience, type of advertisement, ad objective, ad content, and general specifications. Basic rulesnfor the design is also determined at this stage, such as the duration of the ad, target, and others. The result of this stage is a description of the concept in the formnof title, story idea, synopsis, and storyline.

2. Design

This design stage translates the goals into a design that will be a reference in developing this public service advertisement. The results of this design stage are character designs and storyboards.

3. Material Collecting

Material collecting (material collection) is the stage of collecting materials. Materials collected are images, audio, digital photos, videos, and other supporting images. The process carried out at this stage is graphic design, 3D modeling, making a bumper opening, closing, credit title. In practice, this stage can be done in parallel with the steps assembly.

4. Assembly

After the storyboard is made, the next stage is the assembly stage (making). This public service advertisement is based on $2 \mathrm{D}$ and $3 \mathrm{D}$ animation from that these stages are compositing and animation using Adobe After Effects CS6, Blender, sound effects, and music using Audacity, as well as editing and rendering using Adobe Premiere Pro CS6.

5. Testing

The testing phase (testing) is carried out after the manufacturing stage with the run and do a review (preview) whether there is an error or not. At this stage, the product feasibility test is 
carried out using a questionnaire technique to multiple target audiences.

6. Distribution

At the distribution stage, the video results that have been made previously, are uploaded to on social media Facebook, Google Form, and Youtube. Apart from that researchers directly display this public service advertisement to a group of the target community. This is the final stage where the media is ready to watch.

\section{Likert scale}

The Likert scale is used to measure attitudes, opinions, and perceptions of a person or group of people about social phenomena.[9] On the Likert scale, respondents are asked to answer agreement on psychological objects (construct) with 5 answer choices, namely (1) Strongly disagree, (2) Disagree, (3) Neutral, (4) Agree, (5) Strongly agree. The following is an explanation of the percentage limit on each answer choice (item) Likert scale.

Table 1. Definition and Limitation of Likert Scale

\begin{tabular}{|l|l|l|}
\hline Scale & Information & Definition and Limitation \\
\hline 1. & $\begin{array}{l}\text { Strongly Disagree / } \\
\text { Not very good }\end{array}$ & $\begin{array}{l}\text { If the respondent does not } \\
\text { agree 100\% statement }\end{array}$ \\
\hline 2. & Disagree / Not good & $\begin{array}{l}\text { If the respondent partially } \\
\text { agrees } \\
\text { small of the statement or a } \\
\text { maximum of 30\% of the } \\
\text { statements that correspond } \\
\text { to hope }\end{array}$ \\
\hline 3. & Neutral / Good enough & $\begin{array}{l}\text { If the respondent agrees } \\
\text { 50\% or } \\
\text { hesitated between very } \\
\text { good / agree with totally } \\
\text { disagree / good }\end{array}$ \\
\hline 4. & Agree / fine & $\begin{array}{l}\text { If the respondent partially } \\
\text { agrees } \\
\text { the magnitude of the } \\
\text { statement or on the range } \\
70 \% \text { to } 90 \% \text { statement is } \\
\text { appropriate } \\
\text { with expectations }\end{array}$ \\
\hline 5. & $\begin{array}{l}\text { Very Agree / Very } \\
\text { good }\end{array}$ & $\begin{array}{l}\text { If the respondent fully } \\
\text { agrees from } \\
\text { the statement, even more } \\
\text { so than that } \\
\text { expected by the } \\
\text { respondent or more than } \\
91 \% \text { or more than 100\% } \\
\text { expectation } \\
\text { respondents }\end{array}$ \\
\hline & and \\
\hline
\end{tabular}

\section{METHODOLOGY}

The process of making this public service advertisement begins with making the design process, manufacture, and analysis of test results. Design The work on this public service advertisement can be described as follows

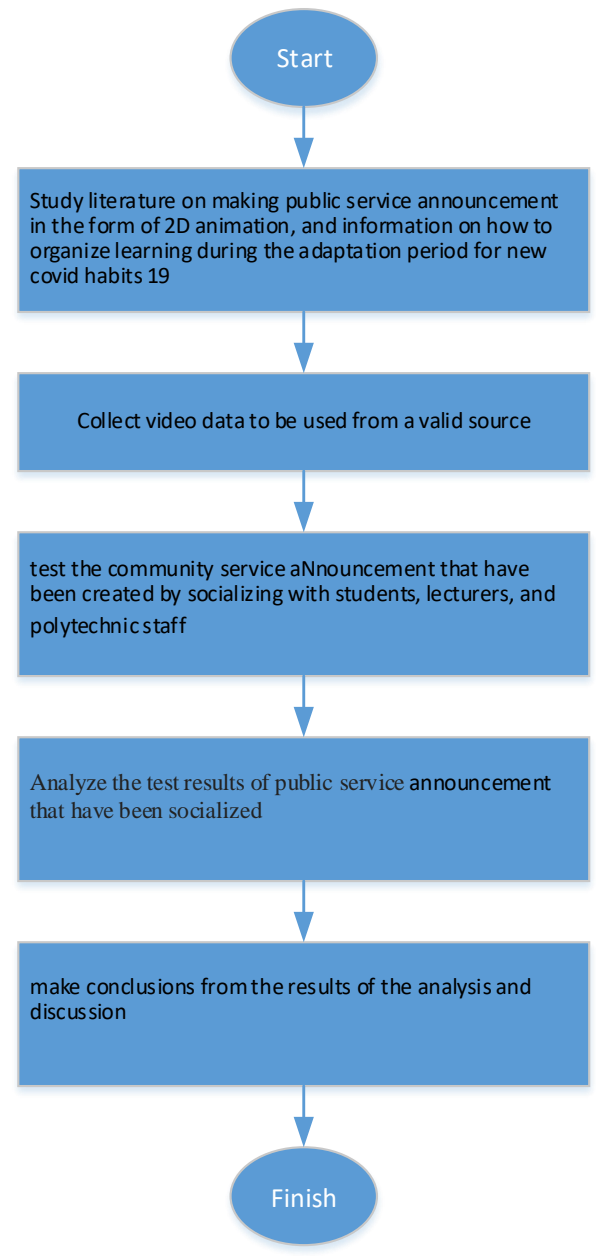

Figure 1. Research flow chart

\section{Design of Public Service Announcement}

In making this $2 \mathrm{D}$ animation-based public service announcement, there are 3 stages. These stages are Pre Production, Production and Post Production. Of the 3 stages, the design of the Public Service Advertisement is included in the section Pre Production which includes a concept description, storyline, and storyboard. Things that are included in the concept description are the title, ad type, target audience, story ideas, synopsis, and message.

\section{Concept Description}

The following is a description of the concept of public service announcement based on 2D animation that the author will create. 
Table 2. Concept Description

\begin{tabular}{|l|l|}
\hline title & $\begin{array}{l}\text { Sriwijaya State Polytechnic Ready to } \\
\text { Face the New Normal }\end{array}$ \\
\hline $\begin{array}{l}\text { type of } \\
\text { advertising }\end{array}$ & public service announcement \\
Audience & $\begin{array}{l}\text { Students, lecturers, and staff of Sriwijaya } \\
\text { State Polytechnic }\end{array}$ \\
\hline Story idea & $\begin{array}{l}\text { Health protocol at Sriwijaya State } \\
\text { Polytechnic for activities that require } \\
\text { face to face }\end{array}$ \\
\hline Synopsis & $\begin{array}{l}\text { The spread of Covid-19 in Indonesia has } \\
\text { not shown any signs } \\
\text { decrease, therefore the Sriwijaya State } \\
\text { Polytechnic in accordance with the letter } \\
\text { decision of the Ministry of Education } \\
\text { and Culture took preventive measures in } \\
\text { the educational environment by } \\
\text { implementing guidelines for the } \\
\text { implementation of education in the } \\
\text { adaptation period of new habits covid19. }\end{array}$ \\
\hline Message & $\begin{array}{l}\text { It is expected that students, lecturers, and } \\
\text { staff of the State Polytechnic Sriwijaya } \\
\text { can carry out guidelines for the } \\
\text { implementation of education have been } \\
\text { informed with discipline. }\end{array}$ \\
\hline
\end{tabular}

\section{Storyline}

The following is a draft storyline for this public service announcement:

Table 3. Design of a Public Service Announcement

\begin{tabular}{|c|c|c|c|}
\hline \multicolumn{4}{|c|}{ Storyline } \\
\hline Scene & Video & Audio & $\begin{array}{l}\text { Estimate } \\
\mathrm{d} \\
\text { Duration }\end{array}$ \\
\hline 1. & $\begin{array}{l}\text { Polytechnic } \\
\text { Sriwijaya is ready to } \\
\text { face it } \\
\text { adaptation period } \\
\text { new covid habit } 19\end{array}$ & $\begin{array}{l}\text { - Backsound } \\
\text { - Sound Effect } \\
\text { - Voice Over }\end{array}$ & 0'10" \\
\hline 2. & $\begin{array}{l}\text { Explanation about } \\
\text { adaptation period } \\
\text { new habit }\end{array}$ & $\begin{array}{l}\text { - Backsound } \\
\text { - Sound Effect } \\
\text { - Voice Over } \\
\end{array}$ & $0^{\prime} 20^{\prime \prime}$ \\
\hline 3. & $\begin{array}{l}\text { Temperature check } \\
\text { body before } \\
\text { enter the area } \\
\text { Polytechnic } \\
\text { Sriwijaya } \\
\end{array}$ & $\begin{array}{l}\text { - Backsound } \\
\text { - Sound Effect } \\
\text { - Voice Over }\end{array}$ & $0^{\prime} 20$ "' \\
\hline 4. & $\begin{array}{l}\text { Explanation of } \\
\text { functions Polyclinic }\end{array}$ & $\begin{array}{l}\text { - Backsound } \\
\text { - Sound Effect } \\
\text { - Voice Over }\end{array}$ & $0^{\prime} 20$ "' \\
\hline 5. & $\begin{array}{l}\text { Keep a distance } \\
\text { from one another }\end{array}$ & $\begin{array}{l}\text { - Backsound } \\
\text { - Sound Effect } \\
\text { - Voice Over } \\
\end{array}$ & $0^{\prime} 10^{\prime \prime}$ \\
\hline 6. & $\begin{array}{l}\text { Manners while in the } \\
\text { elevator }\end{array}$ & $\begin{array}{l}\text { - Backsound } \\
\text { - Sound Effect } \\
\text { - Voice Over }\end{array}$ & 00'15" \\
\hline & & - Backsound & \\
\hline
\end{tabular}

\begin{tabular}{|l|l|l|c|}
\hline & $\begin{array}{l}\text { before entering } \\
\text { lab / classroom }\end{array}$ & $\begin{array}{l}\text { - Sound Effect } \\
\text { - Voice Over }\end{array}$ & \\
\hline 8. & Avoid shaking hands & $\begin{array}{l}\text { - Backsound } \\
- \text { Sound Effect } \\
\text { - Voice Over }\end{array}$ & $0^{\prime} 10^{\prime \prime}$ \\
\hline 9. & $\begin{array}{l}\text { Use your feet or } \\
\text { elbows when } \\
\text { opening } \\
\text { door }\end{array}$ & $\begin{array}{l}\text { - Backsound } \\
- \text { Sound Effect } \\
\text { - Voice Over }\end{array}$ & $00^{\prime}, 10^{\prime \prime}$ \\
\hline 10 & Distance in class & $\begin{array}{l}\text { - Backsound } \\
\text { - Sound Effect } \\
\text { - Voice Over }\end{array}$ & $00^{\prime}, 10^{\prime \prime}$ \\
\hline 11 & $\begin{array}{l}\text { Providing } \\
\text { disinfectant in the } \\
\text { lab and classrooms }\end{array}$ & $\begin{array}{l}\text { - Backsound } \\
\text { - Sound Effect } \\
\text { - Voice Over }\end{array}$ & $00^{\prime}, 10^{\prime \prime}$ \\
\hline 12. & Bring lunch each & $\begin{array}{l}\text { - Backsound } \\
- \text { Sound Effect } \\
\text { - Voice Over }\end{array}$ & $00^{\prime}, 10^{\prime \prime}$ \\
\hline 13. & Closing & $\begin{array}{l}\text { - Backsound } \\
\text { - Sound Effect } \\
\text { - Voice Over }\end{array}$ & $00^{\prime}, 13^{\prime \prime}$ \\
\hline
\end{tabular}

\section{Storyboard}

The storyboard is used as a layout design (layout) of the asset will be used to describe a description of each scene in the service advertisement Public. The following is a storyboard design that will be used in the preproduction stage of this service Announcemen.

\begin{tabular}{|l|l|l|l|l|l|l|}
\hline Scn & 1 & Cut & 1 & Dur & $10 \mathrm{Sec}$ & Information \\
\hline \hline & & & $\begin{array}{l}\text { A female student uses standard personal } \\
\text { protective equipment (PPE), namely a } \\
\text { mask to prevent the spread of the virus } \\
\text { corona }\end{array}$ \\
\hline
\end{tabular}

Figure 2. Design of Public Service Announcement Storyboard

All of these processes are carried out gradually and accordingly scheduling. Each stage of the process must be carefully arranged so that there is no process missed, just one process is skipped will hurt production management resulting in additional production schedules.

\section{Method Development}

In the method development stage, public service advertisements are based This 2D animation uses Luther's multimedia development method. Process this development will be described in the following chart: 


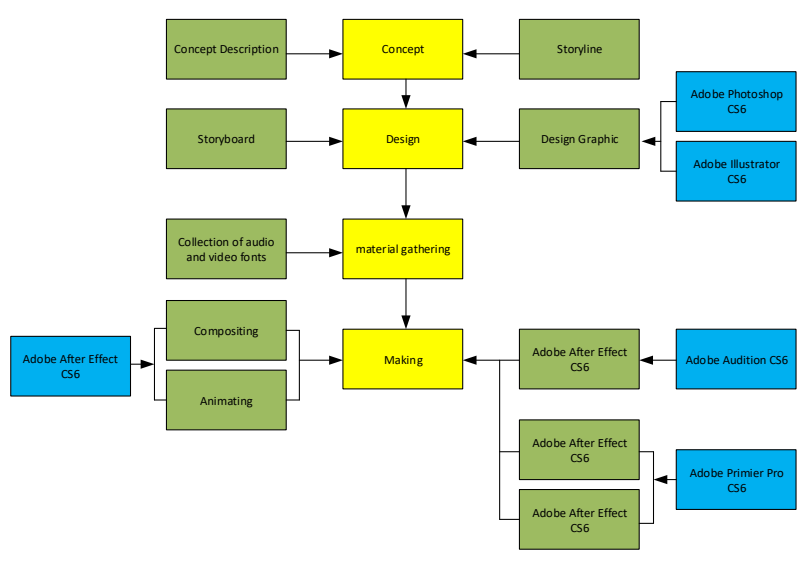

Figure 3. Luther's Multimedia Development Method

In Luther's multimedia method, there are 4 stages, namely concept, design, material gathering, and manufacturing. In its implementation in making Ads 2D animation-based community service regarding waste, in general, the process is divided into several stages, namely:

1. Pre-production, covering the points: Concept and Design (design).

2. Production, including the points: Material collection (audio, video, graphic design).

3. Post-production, covering the points: Making (compositing, editing, rendering).

\section{RESULTS AND DISCUSSION}

Realization of Motion Graphic Animation Videos After completing the design stages, you will get a moving animation video with a resolution of $1920 \mathrm{x}$ 1080 , in MP4 format. This video can be played in almost all video player software, such as: Movie \& TV, VLC Media Player, and Windows Media Player. Following are the results of the motion graphic animation video The Sriwijaya State Polytechnic Learning Implementation Guide for the New Habit Adaptation Period.

\begin{tabular}{|c|c|c|c|}
\hline No & Scene & Information & Narrative \\
\hline 1. & & $\begin{array}{l}\text { displays a } \\
\text { palembang } \\
\text { atmosphere such } \\
\text { as ampera, etc. }\end{array}$ & \\
\hline 2. & $\frac{x+2}{4}+2$ & $\begin{array}{l}\text { displays the } \\
\text { atmosphere of } \\
\text { Palembang with } \\
\text { the spread virus }\end{array}$ & \\
\hline 3. & Aphrias: & $\begin{array}{l}\text { displays video } \\
\text { titles }\end{array}$ & $\begin{array}{l}\text { Sriwijaya State } \\
\text { Polytechnic is ready } \\
\text { to face a period of } \\
\text { adaptation to new } \\
\text { habits. }\end{array}$ \\
\hline 4. & $\begin{array}{c}\text { KUШАН } \\
\text { DARIIIG }\end{array}$ & $\begin{array}{l}\text { displays footage } \\
\text { about online } \\
\text { lectures }\end{array}$ & $\begin{array}{l}\text { Teaching and } \\
\text { learning activities } \\
\text { are carried out } \\
\text { online, but activities }\end{array}$ \\
\hline
\end{tabular}

\begin{tabular}{|c|c|c|c|}
\hline & & & $\begin{array}{l}\text { such as practicum } \\
\text { and research can be } \\
\text { carried out face-to- } \\
\text { face by complying } \\
\text { with health } \\
\text { protocols. }\end{array}$ \\
\hline 5. & 6 & $\begin{array}{l}\text { show standard apd } \\
\text { footage }\end{array}$ & $\begin{array}{l}\text { Use standard PPE } \\
\text { such as a mask or } \\
\text { faceshield. }\end{array}$ \\
\hline 6. & 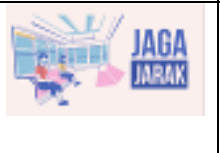 & $\begin{array}{l}\text { displays the } \\
\text { footage keep the } \\
\text { distance in public } \\
\text { transportation }\end{array}$ & $\begin{array}{l}\text { When on public } \\
\text { transportation, avoid } \\
\text { crowds and keep } \\
\text { your distance from } \\
\text { others. }\end{array}$ \\
\hline 7. & & $\begin{array}{l}\text { displays body } \\
\text { temperature check } \\
\text { footage }\end{array}$ & $\begin{array}{l}\text { Check the body } \\
\text { temperature, if the } \\
\text { temperature is below } \\
37 \text { degrees it is } \\
\text { allowed to enter the } \\
\text { campus area, but if it } \\
\text { is above } 37 \text { degrees, } \\
\text { you are instructed to } \\
\text { go to the polyclinic } \\
\text { for further } \\
\text { examination. }\end{array}$ \\
\hline 8. & & $\begin{array}{l}\text { displays the } \\
\text { footage of the } \\
\text { break at home }\end{array}$ & $\begin{array}{l}\text { If you feel sick you } \\
\text { should stay at home. }\end{array}$ \\
\hline 9. & & $\begin{array}{l}\text { Displays distance } \\
\text { distance footage } \\
\text { when interacting }\end{array}$ & $\begin{array}{l}\text { keep a minimum } \\
\text { distance from each } \\
\text { other } 1.5 \mathrm{M} \text {. }\end{array}$ \\
\hline 10. & t) & $\begin{array}{l}\text { displays the } \\
\text { footage standing } \\
\text { according to the } \\
\text { sign on the lift }\end{array}$ & $\begin{array}{l}\text { When in the } \\
\text { elevator, you are } \\
\text { required to stand } \\
\text { according to the } \\
\text { designated signs. }\end{array}$ \\
\hline 11. & afy & $\begin{array}{l}\text { show footage } \\
\text { avoid shaking } \\
\text { hands }\end{array}$ & $\begin{array}{l}\text { Avoid shaking } \\
\text { hands. }\end{array}$ \\
\hline 12 & 》 & $\begin{array}{l}\text { displays the } \\
\text { footage of } \\
\text { washing hands } \\
\text { before entering the } \\
\text { lab / class }\end{array}$ & $\begin{array}{l}\text { Before entering the } \\
\text { lab or class, it is } \\
\text { mandatory to wash } \\
\text { your hands with soap } \\
\text { or use a hand } \\
\text { sanitizer. }\end{array}$ \\
\hline 13 & 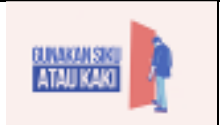 & $\begin{array}{l}\text { displays the } \\
\text { footage of opening } \\
\text { the door with your } \\
\text { feet }\end{array}$ & $\begin{array}{l}\text { Use your elbows or } \\
\text { feet to open the door. }\end{array}$ \\
\hline 14 & 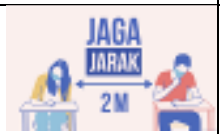 & $\begin{array}{l}\text { displays footage } \\
\text { keeping spacing in } \\
\text { class }\end{array}$ & $\begin{array}{l}\text { When in class, make } \\
\text { sure the distance } \\
\text { between students is } \\
\text { more than } 2 \mathrm{M} \text {. }\end{array}$ \\
\hline
\end{tabular}




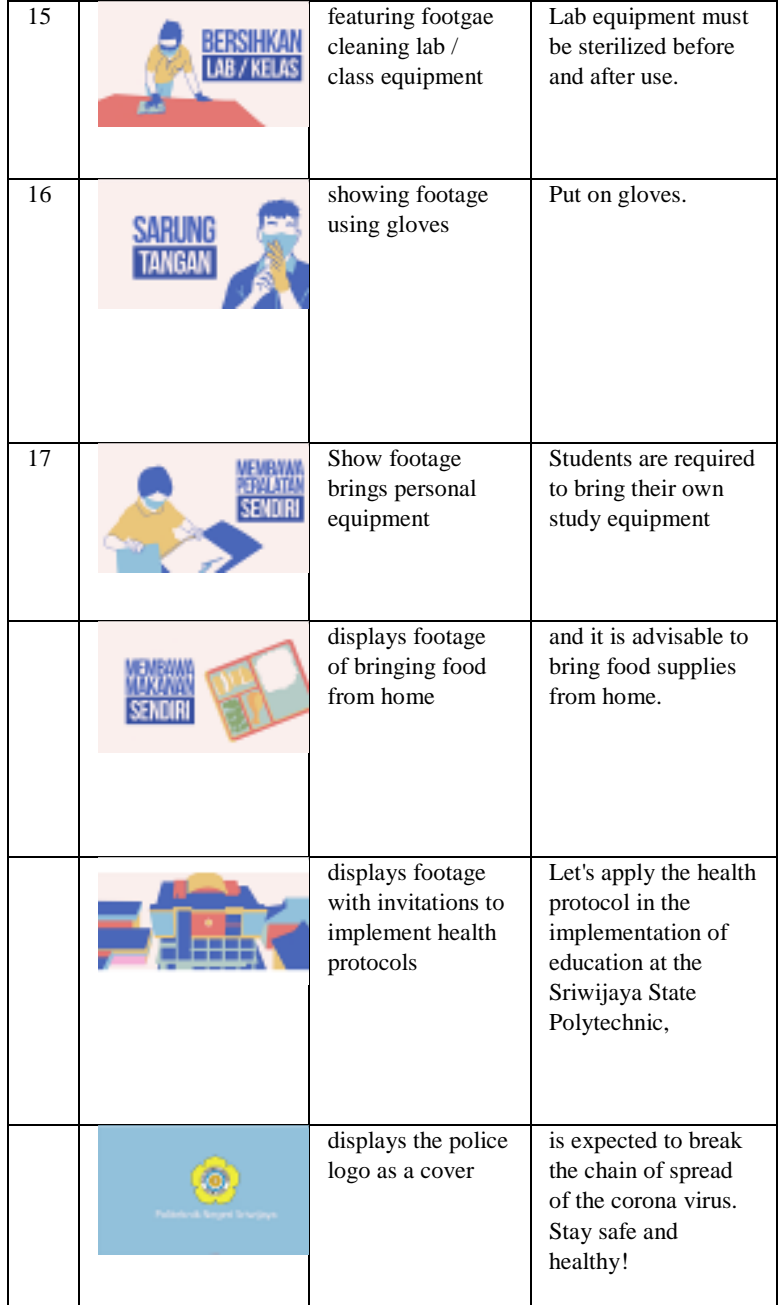

\subsection{Testing of Respondents}

This motion graphic animation video test was conducted on 40 respondents aged 21-40 years and over. This test is performed on August 17, 2020. Respondents are people with a minimum education level is SMA / MA / SMK to S2. Response testing is aimed at providing the conclusion that the video is animated This motion graphic is worthy or not to be watched and published. Testing is done by sharing a URL (UniformResource Locator) contains a questionnaire in google format form, to students, lecturers, practitioners, and employees of the State PolytechnicSriwijaya Palembang, through social media facilities such as Instagram and WhatsApp.

The questionnaire was conducted to collect respondents' biodata, data in terms of appearance, and data in terms of information content. Data were taken in the respondent's biodata, namely: Email, name, age, gender, level of education, and employment. As for some of the questions that are contained in the questionnaire, namely as in the table 4 .
Table 4. Questions In terms of appearance.

\begin{tabular}{|c|c|c|c|c|c|c|}
\hline No & question & \multicolumn{5}{|c|}{ Answer options } \\
\hline 1. & $\begin{array}{l}\text { Is this video } \\
\text { interesting in terms } \\
\text { of images/graphics? }\end{array}$ & SS & ST & RG & TS & STS \\
\hline 2. & $\begin{array}{l}\text { Is this video } \\
\text { interesting in terms } \\
\text { of } \\
\text { color? }\end{array}$ & & & & & \\
\hline 3. & $\begin{array}{l}\text { Is this video } \\
\text { interesting in terms } \\
\text { of } \\
\text { typography (text)? }\end{array}$ & & & & & \\
\hline 4. & $\begin{array}{l}\text { Is this video } \\
\text { interesting in terms } \\
\text { of } \\
\text { animation? }\end{array}$ & & & & & \\
\hline 5. & $\begin{array}{l}\text { Is this video } \\
\text { interesting in terms } \\
\text { of } \\
\text { audio? }\end{array}$ & & & & & \\
\hline
\end{tabular}

Table 5. Questions in terms of information content.

\begin{tabular}{|c|c|c|c|c|c|c|}
\hline No & question & \multicolumn{5}{|c|}{ Answer options } \\
\hline 1. & $\begin{array}{l}\text { Is the information } \\
\text { from this video easy } \\
\text { to understand? }\end{array}$ & SS & ST & RG & TS & STS \\
\hline 2. & $\begin{array}{l}\text { Is that amount of } \\
\text { information } \\
\text { provided complete? }\end{array}$ & & & & & \\
\hline 3. & $\begin{array}{l}\text { Is the delivery of } \\
\text { information with a } \\
\text { motion graphic } \\
\text { approach like this is } \\
\text { easy for you to } \\
\text { understand? }\end{array}$ & & & & & \\
\hline 4. & $\begin{array}{l}\text { Is this video capable } \\
\text { of delivering } \\
\text { information to the } \\
\text { public regarding } \\
\text { guidelines for the } \\
\text { implementation of } \\
\text { education in } \\
\text { Sriwijaya State } \\
\text { Polytechnic }\end{array}$ & & & & & \\
\hline
\end{tabular}

\subsection{Test Result Data Against Respondents}

The number of respondents was 40 people. By the type of question is divided into two categories, namely in terms of appearance and information content. Where at every section have several different questions.

Table 6. Distribution of Respondents Based on the Question "What is this video Interesting from an image / graphic point of view

\begin{tabular}{|l|c|c|}
\hline \multicolumn{1}{|c|}{ score } & $\begin{array}{c}\text { number of } \\
\text { respondents }\end{array}$ & percentage \\
\hline strongly agree & 31 & $77,5 \%$ \\
\hline agree & 9 & $22,5 \%$ \\
\hline Doubtful & 0 & $0 \%$ \\
\hline
\end{tabular}




\begin{tabular}{|l|c|c|}
\hline disagree & 0 & $0 \%$ \\
\hline totally disagree & 0 & $0 \%$ \\
\hline Total & 40 & $100 \%$ \\
\hline
\end{tabular}

ACKNOWLEDGMENTS

The authors acknowledge funding support from State Polytechnic of Sriwijaya. The authors also regard thanks to all civitas academic State Polytechnic of Sriwijaya for motivation and help.

\section{REFERENCES}

[1] Panduan Penyelenggaraan Pembelajaran Semester Gasal 2020/2021 di Perguruan Tinggi, Direktorat Jenderal Pendidikan Tinggi Kemdikbud RI, 2020.

[2] Albardon. 2010. About the Definition of Animation. Uploaded on 22 August 2010. Downloaded on 12 February 2019. https://en.svhoong.com/internet-andtechnologies/software/2040864-definisi-animan/

[3] A Compoundila, Gerzon. R. 2017. Documentary: From Idea to Production. Jakarta: Faculty of Film and Television, Jakarta Arts Institute.

[4] Dwihantoro, Prihatin. 2010. Designing Public Service Advertisements as a Mangrove Forest
Conservation Campaign in Tugu Semarang. Malang: State University of Malang.

[5] Maulana, Andrian. 2015. Animation-based Public Service Advertisements for Caries Disease Prevention in Children. Journal of E-Proceedings. $2(2): 629$.

[6] Purwanto, Agus \& Amir Fatah Sofyan. 2008. Digital Multimedia: Animation, Sound Editing, \& Video Editing. Yogyakarta: Andi.

[7] Ruslan, Arief. 2016. Animation Development and the Concept. Bogor: Ghalia Indonesia.

[8] Saputra, Kenny Clinton, et al. 2017. Public Service Advertisements as Alternative Solutions for Handling Children with ADHD. Adiwarna DKV Journal. 1 (9): 2-4.

[9] Sugiyono. 2012. Quantitative Research Methods, Qualitative, and R \& D. Bandung: Alfabeta.

[10] Syarif, Ari Maulana \& Yoga Haris Al Ahdaf. 2017. Public Service Advertisement for 2D Animation of Water Pollution Prevention in Semarang City. Informatics Engineering Library. Faculty of Computer Science. Dian Nuswantoro University Semarang. 